\title{
Vitamin D deficiency: A potential risk factor for Clostridium difficile infection
}

This article was published in the following Dove Press journal:

Risk Management and Healthcare Policy

5 October 2012

Number of times this article has been viewed

\author{
Dima Youssef' \\ William B Grant ${ }^{2}$ \\ Alan N Peiris ${ }^{3,4}$ \\ 'Department of Internal Medicine, \\ Division of Infectious Diseases, \\ ${ }^{2}$ Sunlight, Nutrition and Health \\ Research Center, San Francisco, \\ CA USA; ${ }^{3}$ Department of Medicine, \\ Mountain Home VAMC, ${ }^{4}$ Department \\ of Medicine, East Tennessee State \\ University, Johnson City, Tennessee, \\ USA
}

In the July 3, 2012 issue of the journal of Risk Management and Healthcare Policy, Martinez et al present a nice review on Clostridium difficile (C. difficile) infections. ${ }^{1}$ The different manifestations of this challenging disease along with the high cost and burden on the health care system were discussed. While the authors did an admirable job in discussing traditional risk factors, they do not mention vitamin D deficiency.

Vitamin D deficiency has reached a pandemic status. ${ }^{2}$ Vitamin D has an important role in boosting the innate immunity, and thus preventing infections. ${ }^{3}$ We have recently reviewed the potential role of vitamin $\mathrm{D}$ in the prevention of hospital acquired infections. ${ }^{4}$ In a veterans study, vitamin $\mathrm{D}$ deficiency in patients with $C$. difficile was associated with significantly increased total costs and fee-based consultation. The deficient patients had five times higher costs than the non-deficient patients. ${ }^{5}$ Most cells have vitamin D receptors and vitamin D has a plethora of actions leading to boosting innate immunity including increased oxidative burst of macrophages and enhancing neutrophil motility and phagocytic function, $\mathrm{T}$ cell activation and increased expression of antimicrobial peptides, such as cathelicidin, and beta-defensins. While awaiting additional confirmatory studies of the antimicrobial effects of vitamin $\mathrm{D}$, there are sufficient benefits including better intensive care unit outcomes, ${ }^{6}$ for the authors to include a vitamin D replete state as a part of their therapeutic approach. Vitamin D is inexpensive and has the potential to tilt the balance in favor of patients with this devastating infection.

\section{Acknowledgments}

This material is the result of works supported with resources and the use of facilities at the Mountain Home VAMC. The contents of this report do not reflect the position of the US government and the Department of Veterans Affairs.

\section{Disclosure}

WBG receives funding from the UV Foundation (McLean, VA), Bio-Tech Pharmacal (Fayetteville, AR), the Vitamin D Council (San Luis Obispo, CA), the Vitamin D Society (Canada), and the Sunlight Research Forum (Veldhoven).

\section{References}

1. Martinez FJ, Leffler DA, Kelly CP. Clostridium difficile outbreaks: prevention and treatment strategies. Risk Manag Healthc Policy. 2012;5:55-64.

2. Holick MF. Vitamin D deficiency. N Engl J Med. 2007;357(3):266-281. submit your manuscript | www.dovepress.com

Dovepress

http://dx.doi.org/10.2147/RMHP.S36781
Risk Management and Healthcare Policy 2012:5 II5-II6

(C) 2012 Youssef et al, publisher and licensee Dove Medical Press Ltd. This is an Open Access article which permits unrestricted noncommercial use, provided the original work is properly cited. 
3. Youssef DA, Miller CW, El-Abbassi AM, et al. Antimicrobial implications of vitamin D. Dermatoendocrinol. 2011;3(4):220-229.

4. Youssef D, Ranasinghe T, Grant WB, Peiris AN. Vitamin D's potential to reduce the risk of hospital-acquired infections. Dermatoendocrinol. Apr/May/Jun 2012;4(2):1-9.

5. Youssef D, Bailey B, El Abbassi A, et al. Healthcare costs of Staphylococcus aureus and Clostridium difficile infections in veterans: role of vitamin D deficiency. Epidemiol Infect. 2010;138(9):1322-1327.
6. Matthews LR, Ahmed Y, Wilson KL, Griggs DD, Danner OK. Worsening severity of vitamin D deficiency is associated with increased length of stay, surgical intensive care unit cost, and mortality rate in surgical intensive care unit patients. Am J Surg. 2012;1(204):37-43.

\section{Publish your work in this journal}

Risk Management and Healthcare Policy is an international, peerreviewed, open access journal focusing on all aspects of public health, policy, and preventative measures to promote good health and improve morbidity and mortality in the population. The journal welcomes submitted papers covering original research, basic science, clinical \& epidemio- logical studies, reviews and evaluations, guidelines, expert opinion and commentary, case reports and extended reports. The manuscript management system is completely online and includes a very quick and fair peerreview system, which is all easy to use. Visit http://www.dovepress.com/ testimonials.php to read real quotes from published authors.

Submit your manuscript here: http://www.dovepress.com/risk-management-and-healthcare-policy-journal 